\title{
Sosialisasi dan Edukasi Pemanfaatan Limbah Kulit Pisang sebagai Masker Wajah Alami Kaya Antioksidan di Kecamatan Marpoyan Damai Pekanbaru
}

\author{
Putri Ade Rahma Yulis ${ }^{1}$, Yelfira Sari ${ }^{2}$, Desti ${ }^{2}$ \\ 1,2 Universitas Islam Riau
}

\begin{tabular}{l} 
Article History \\
\hline Received 14.08.2019 \\
Received in revised form \\
21.11.2019 \\
Accepted 03.12.2019 \\
Available online 16.12.2019
\end{tabular}

\begin{abstract}
SOCIALIZATION AND EDUCATION ON THE UTILIZATION OF BANANA SKIN WASTE AS ANTIOXIDANT-RICH NATURAL FACE MASKS IN MARPOYAN DAMAI DISTRICT, PEKANBARU. The fact at this time is the increasing level of consumer consumption of beauty products. It does not only occur among adult women but also teenager. But the consumptive level not accompanied by purchasing power of quality products. Based on interviews with residents of the village of East Sidomulyo, most of the citizens are among adult women and teenagers that they mostly use ready-made masks that are sold in the market because it is more practical and faster in the process of use without considering the possibility of its contents which are harmful to skin health. The problem of the partners is to encourage service in the form of socialization and education to the local community to be able to take advantage of the banana peel waste that is widely available in the environment because it is now became popular a variety of processed banana products, but in terms of waste has not been utilized at all. This education is based on several studies that banana peels contain high antioxidants so it is very good if it can be processed as a mask for a facial skin care. In addition, the utilization of waste will be able to reduce pollution that might occur in the environment due to banana peels that are not treated. The existence of this activity was very welcomed by residents, this can be seen from the enthusiasm of residents asking questions regarding the problems presented and the impression of some residents who want this activity to be carried out continuously, so that more people feel the benefits and they are very enthusiastic to directly apply the knowledge.
\end{abstract}

KEYWORDS: Clean Water, Filtration, Water Treatment. Attribution 4.0 International License, which permits unrestricted use, distribution, and reproduction in any medium, provided the original work is properly cited. c) 2019 Putri Ade Rahma Yulis, Yelfira Sari, Desti.

\footnotetext{
${ }^{3}$ Corresponding author: Universitas Islam Riau. Jl. Kaharuddin Nst No.113, Simpang Tiga, Kec. Bukit Raya, Kota Pekanbaru, Riau 28284
} Indonesia. Email: putriaderahmayulis@edu.uir.ac.id 


\section{PENDAHULUAN}

Banyaknya jumlah perempuan dewasa dan remaja di Indonesia meningkatkan produksi produk-produk kecantikan, namun dikarenakan tingkat perekonomian yang masih tergolong rendah mengakibatkan rendahnya daya beli terhadap produk-produk berkualitas dengan tawaran harga yang cukup mahal. Hal ini mendorong munculnya produk-produk tiruan yang jauh lebih murah sehingga dapat menjangkau pangsa pasar yang cukup besar. Namun produk-produk tersebut diketahui biasanya mengandung bahan-bahan kimiawi yang cukup berbahaya yang dapat menimbulkan permasalahan pada kulit baik secara langsung ataupun setelah terakumulasi dalam jangka waktu panjang. Salah satu produk kecantikan yang sedang marak dipergunakan saat ini adalah masker wajah yang diketahui dapat mengatasi berbagai persoalan kulit wajah diantaranya dapat mencerahkan kulit, mengatasi jerawat, melembabkan wajah, menghilangkan flek hitam, dan permasalahan yang biasa muncul pada wajah.

Indonesia per tahun 2010 masuk kedalam 10 besar pada urutan ke enam sebagai produsen buah pisang terbesar di dunia dengan jumlah produksi sebesar 5,814,580 ton (Padam, Tin, Chye, \& Abdullah, 2014). Hal ini menggambarkan potensi yang cukup besar untuk pemanfaatan pisang dan limbah kulit pisang. Di daerah Riau khususnya di Pekanbaru, sangat banyak aneka makanan olahan yang berasal dari pisang seperti pisang goreng, pisang goreng kipas, keripik pisang, nugget pisang, pisang keju dan sebagainya. Limbah dari pengolahan kulit pisang tersebut belum diolah lebih lanjut.

Berdasarkan beberapa penelitian kulit pisang mengandung antioksidan yang tinggi, dan kandungan antioksidan ini sangat bagus bagi kulit terutama kulit wajah. Kulit pisang sumber yang kaya pati (3\%), protein (6-9\%), lemak (3,8-11\%), total serat $(43.2-49.7 \%)$, dan asam lemak tak jenuh, pektin, asam amino dan mikronutrien $(\mathrm{K}, \mathrm{P}, \mathrm{Ca}, \mathrm{Mg})$ (Hadisoewignyo, Foe, \& Tjandrawinata, 2017). Selain itu kulit pisang juga kaya dengan berbagai antioksidan (Fidrianny, Anggraeni, \& Insanu, 2018). Saat ini sedang berkembang pembuatan masker organic yang berasal dari aneka macam tumbuhan dan salah satunya adalah dari limbah kulit pisang. Namun, berdasarkan wawancara masih banyak warga yang belum tau secara signifikan manfaat dari kulit pisang, sehingga tim pengabdian dari prodi Pendidikan Kimia UIR merasa perlunya mengadakan sosialisasi dan edukasi terkait hal ini, yaitu Sosialiasi dan Edukasi Pemanfaatn Limbah Kulit Pisang Sebagai Masker Wajah Alami Yang Kaya Antioksidan" sehingga harapannya warga setempat dapat terhindar dari kosmetik yang berbahaya dan dapat memanfaatkan bahan yang tersedia di lingkungan sekitar yang mempunyai kandungan atau manfaat yang jauh lebih aman dibandingkan kosmetik di pasaran.

\section{METODE PELAKSANAAN}

Kegiatan pengabdian ini dilaksanakan di RT 009 RW 006 Kelurahan Sidomulyo Timur Kecamatan Marpoyan Damai Kota Pekanbaru, Riau. Kegiatan pengabdian telah dilaksanakan pada bulan Juli 2019.

Penerapan Ipteks yang dilakukan adalah dengan melakukan pemaparan kepada warga peserta pengabdian tentang pentingnya memilih produk yang berkualitas terutama untuk perawatan kulit wajah karena terutama mengenai pemilihan masker yang sekarang sedang menjadi trend. Kemudian diberikan edukasi bahwa limbah kulit pisang dapat dijadikan salah satu pengganti masker wajah alami yang mengandung antioksidan 
yang cukup tinggi melalui presentasi Power Point (PPT). Kemudian dilakukan praktek mengenai pemanfaatan limbah kulit pisang tersebut oleh beberapa warga dan dirasakan manfaat singkatnya yang langsung dirasakan.

\section{Kontribusi dan Partisipasi Mitra}

Mitra diharapkan sepakat untuk ikut berpartisipasi aktif dalam kegiatan pengabdian kepada masyarakat yang akan dilaksanakan. Mitra ikut memberikan sumbangsih berupa tenaga, fikiran dan jasa dalam kegiatan yang akan dilaksanakan

\section{Evaluasi dan Keberlanjutan Program}

Untuk keberlanjutan program ini diharapkan agar warga yang sebelumnya menggunakan masker dipasaran yang tidak memperhatikan kandungannya beralih menggunakan limbah kulit pisang secara teratur dan melihat perkembangan perbaikan kulit wajahnya dalam beberapa minggu kedepan setelah pelaksanaan pengabdian dilakukan.

\section{HASIL DAN PEMBAHASAN}

Pelaksanaan kegiatan pengabdian berupa Sosialiasi dan Edukasi Pemanfaatan Limbah Kulit Pisang Sebagai Masker Wajah Alami Yang Kaya Antioksidan telah dilaksanakan di RT. 009 RW. 006 Kelurahan Sidomulyo Timur Kecamatan Marpoyan Damai Kota Pekanbaru-Riau. Kegiatan pengabdian dilaksanakan pada bulan Juli 2019 yang terdiri dari beberapa tahapan kegiatan yang dirinci sebagai berikut:

\section{Identifikasi Awal}

Berdasarkan hasil identifikasi berupa wawancara dengan salah satu warga kelurahan Sidomulyo Timur yang sebagian besar warganya adalah dari kalangan wanita dewasa dan remaja bahwa mereka sebagian besar memang menggunakan masker siap pakai yang dijual dipasaran karena lebih praktis dan cepat dalam proses pemakaiannya tanpa mempertimbangkan kemungkinan kandungan nya yang berbahaya bagi kesehatan kulit.

\section{Kegiatan Sosialiasi dan Edukasi Pemanfaatan Limbah Kulit Pisang}

Pelaksanaan kegiatan dilakukan pada bulan Juli 2019 di daerah Kelurahan Sidomulyo Timur tepatnya di Beringin Indah Pala Raya. Kegiatan ini dihadiri kurang lebih 15 peserta, kemudian ditambah 3 orang Tim Dosen Universitas Islam Riau dan 2 orang mahasiswa Pendidikan Kimia, jumlah yang tidak terlalu banyak ini disebabkan beberapa peserta berhalangan hadir dalam mengikuti kegiatan sosialisasi ini dikarenakan beberapa hal yang mendadak setelah dikonfirmasi oleh ketua mitra dalam pelaksanaan pengabdian ini.

Adapun tahapan pelaksanaan kegiatan setelah dibuka oleh mitra kemudian dilanjutkan oleh tim pengabdian untuk memberikan edukasi seputar tujuan diadakannya pengabdian dengan tema terpilih kemudian pemaparan mengenai sumber -sumber radikal bebas dan contoh penanggulangan dari paparan radikal bebas tersebut serta dampak yang diakibatkan nya terutama untuk kulit wajah sebagai bagian paling sensitif 
terutama bagi wanita serta cara untuk menangkal radikal tersebut. Salah satunya adalah dengan memnafaatkan senyawa yang kaya antioksidan. Kemudian juga dilakukan pemaparan mengenai antioksidan dan sumber-sumber antioksidan tersebut. Setelah diberikan Edukasi kemudian dilanjutkan sosialiasi terkait hasil penelitian pendahuluan salah satu tim pengabdian didukung penelitian -penelitian lainnya bahwa salah satu limbah yang sangat banyak terdapat di sekitar masyarakat saat ini yaitu kulit pisang yang masih terbilang minim pemanfaatannya ternyata merupakan sumber antioksidan yang cukup tinggi dan mempunyai komponen aktif yang sangat kompleks sehingga sangat baik jika diaplikasikan sebagai masker wajah untuk menggantikan ketergantungan warga yang terbiasa memakai masker yang ada di pasaran. Setelah pemaparan tim pengabdian kemudian dilanjutkan dengan diskusi terkait pemanfaatan limbah kulit pisang.

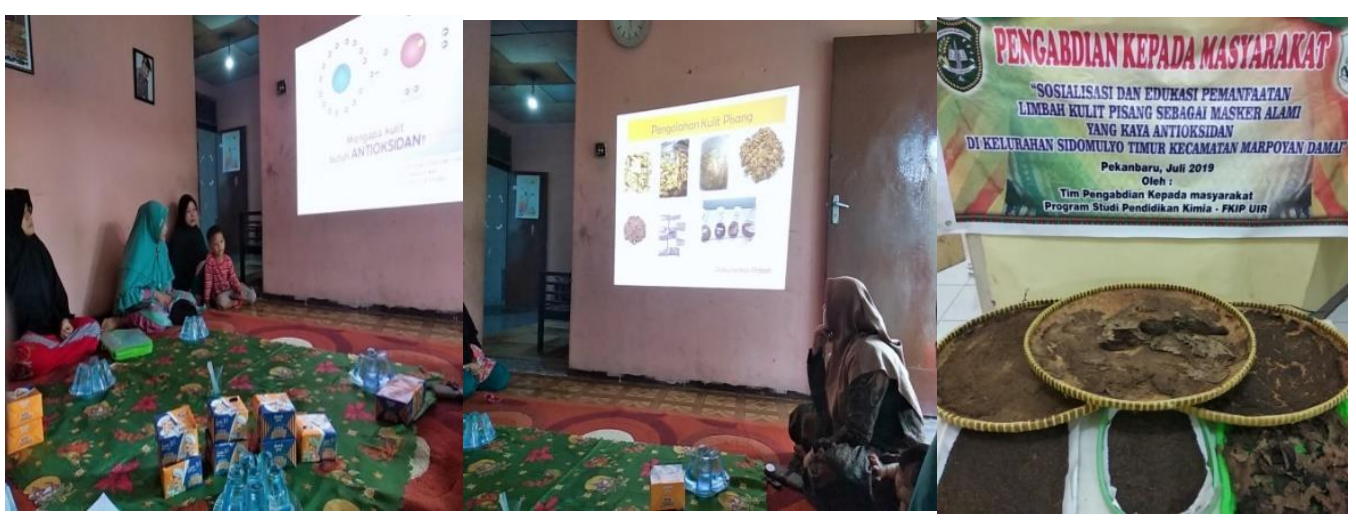

Gambar 1. Pemaparan terkait Antioksidan dan Langkah Pemanfaatan Limbah Kulit Pisang

Beberapa penelitian terkait kandungan kulit pisang yang dipaparkan diantaranya penelitian (Jami'ah, Ifaya, Pusmarani, \& Nurhikma, 2018) yang mengungkapkan bahwa ekstrak kulit pisang Raja memiliki aktivitas antioksidan yang sangat kuat dengan nilai IC 50 sebesar 46,82 ppm. Kemudian (Alhabsyi, 2014) penelitian nya menunjukkan bahwa ekstrak kulit buah pisang goroho mengandung senyawa fenolik, flavonoid dan tanin. Ekstrak etanol memiliki nilai aktivitas antioksidan yang paling tinggi yaitu 75,71\%. (Paul, 2014) melaporkan bahwa kulit pisang mengandung beberapa jenis antioksidan seperti gallocatechin and dopamine.

Diskusi berjalan cukup efektif hal ini dilihat dari sangat antusiasnya peserta menanyakan proses pemakaian kulit pisang tersebut dan kemungkinan manfaat-manfaat yang dapat mereka peroleh dan para peserta sangat mengharapkan tim pengabdian untuk terus dapat menginformasikan perkembangan terkait penelitian limbah kulit pisang ini serta dapat diteruskan ke beberapa kelompok ibu-ibu PKK yang ada disekitar daerah tersebut dan beberapa peserta langsung mengatakan akan mencoba mengaplikasikan langsung informasi yang telah disampaikan tim pengabdian.

\section{SIMPULAN}

Kegiatan pengabdian masyarakat ini disambut baik karena memberikan dampak yang positif, dimana dengan adanya forum diskusi mendorong munculnya kesadaran masyarakat mengenai bahayanya penggunaan perawatan wajah yang tidak diidentifikasi dengan jelas, kemudian masyarakat menjadi lebih tau mengenai faktor -faktor yang berpengaruh terhadap masalah yang muncul pada kulit khususnya di area wajah dan 
cara-cara alami yang dapat dimanfaatkan untuk tetap dapat melakukan perawatan wajah tanpa khawatir efek sampingnya.

\section{REFERENCES}

Alhabsyi, D. F. (2014). Aktivitas antioksidan dan tabir surya pada ekstrak kulit buah pisang goroho (Musa acuminate L.). PHARMACON, 3(2), 107-114.

Fidrianny, I., Anggraeni, N. A. S., \& Insanu, M. (2018). Antioxidant properties of peels extracts from three varieties of banana (Musa sp.) grown in West Java-Indonesia. International Food Research Journal, 25(1), 57-64.

Hadisoewignyo, L., Foe, K., \& Tjandrawinata, R. R. (2017). Isolation and characterization of Agung banana peel starch from East Java Indonesia. International Food Research Journal, 24(3), 1324.

Jami'ah, S. R., Ifaya, M., Pusmarani, J., \& Nurhikma, E. (2018). Uji aktivitas antioksidan ekstrak metanol kulit pisang raja (Musa paradisiaca sapientum) dengan metode DPPH (2, 2-Difenil-1-Pikrilhidrazil). Jurnal Mandala Pharmacon Indonesia, 4(1), 33-38.

Padam, B. S., Tin, H. S., Chye, F. Y., \& Abdullah, M. I. (2014). Banana by-products: an under-utilized renewable food biomass with great potential. Journal of Food Science and Technology, 51(12), 3527-3545.

Paul, S. K. D. \& R. K. \& D. (2014). Comparative antioxidant effect of BHT and water extracts of banana and sapodilla peels in raw poultry meat. Journal of Food Science and Technology, 51(2), 387-391. 